\title{
Tree species and functional traits but not species richness affect interrill erosion processes in young subtropical forests
}

\author{
S. Seitz ${ }^{1}$, P. Goebes ${ }^{1}$, Z. Song ${ }^{1}$, H. Bruelheide ${ }^{2,3}$, W. Härdtle ${ }^{4}$, P. Kühn ${ }^{1}$, Y. Li ${ }^{4}$, and T. Scholten ${ }^{1}$ \\ ${ }^{1}$ Department of Geosciences, Soil Science and Geomorphology, Eberhard Karls University Tübingen, \\ Rümelinstrasse 19-23, 72070 Tübingen, Germany \\ ${ }^{2}$ Geobotany and Botanical Garden, Martin Luther University Halle-Wittenberg, Am Kirchtor 1, 06108 Halle, \\ Germany \\ ${ }^{3}$ German Centre for Integrative Biodiversity Research (iDIV) Halle-Jena-Leipzig, Deutscher Platz 5e, \\ 04103 Leipzig, Germany \\ ${ }^{4}$ Institute of Ecology, Faculty of Sustainability, Leuphana University Lüneburg, Scharnhorststrasse 1, \\ 21335 Lüneburg, Germany
}

Correspondence to: S. Seitz (steffen.seitz@uni-tuebingen.de)

Received: 13 May 2015 - Published in SOIL Discuss.: 24 June 2015

Revised: 20 November 2015 - Accepted: 12 December 2015 - Published: 21 January 2016

\begin{abstract}
Soil erosion is seriously threatening ecosystem functioning in many parts of the world. In this context, it is assumed that tree species richness and functional diversity of tree communities can play a critical role in improving ecosystem services such as erosion control. An experiment with 170 micro-scale run-off plots was conducted to investigate the influence of tree species and tree species richness as well as functional traits on interrill erosion in a young forest ecosystem. An interrill erosion rate of $47.5 \mathrm{Mg} \mathrm{ha}^{-1} \mathrm{a}^{-1}$ was calculated. This study provided evidence that different tree species affect interrill erosion differently, while tree species richness did not affect interrill erosion in young forest stands. Thus, different tree morphologies have to be considered, when assessing soil erosion under forest. High crown cover and leaf area index reduced interrill erosion in initial forest ecosystems, whereas rising tree height increased it. Even if a leaf litter cover was not present, the remaining soil surface cover by stones and biological soil crusts was the most important driver for soil erosion control. Furthermore, soil organic matter had a decreasing influence on interrill erosion. Long-term monitoring of soil erosion under closing tree canopies is necessary, and a wide range of functional tree traits should be considered in future research.
\end{abstract}

\section{Introduction}

Soil erosion is considered as one of the most severe environmental challenges globally (Morgan, 2005). It is also a serious challenge in the PR China, especially in the southern tropical and subtropical zone. Although important improvements in erosion control have been achieved in this area in the last decades (Zhao et al., 2013), the annual soil loss rates range between 0.28 and $113 \mathrm{Mg} \mathrm{ha}^{-1}$ (Guo et al., 2015). Thereby, soil erosion negatively affects, e.g., soil fertility and nutrient cycling (Pimentel et al., 1995; Richter, 1998).
Soil erosion can negatively influence biodiversity ( $\mathrm{Pi}$ mentel and Kounang, 1998), but it is assumed that this relationship also acts vice versa (Körner and Spehn, 2002; Geißler et al., 2012b; Brevik et al., 2015). It has been shown that a change in biodiversity can have remarkable effects on ecosystem functions and stability (e.g. Hooper et al., 2005; Scherer-Lorenzen, 2005). In many cases, increasing biodiversity enhanced ecosystem productivity and stability (Loreau, 2001; Jacob et al., 2010). In particular, tree species richness (the diversity of tree species) as well as functional diversity (the diversity of functional traits as morpho- 
physiophenological attributes of a given species; cf. Violle et al., 2007) of tree communities can play a critical role in improving ecosystem services such as water filtration or climate regulation (Quijas et al., 2012; Chisholm et al., 2013; Scherer-Lorenzen, 2014). As forests are generally considered beneficial for erosion control, afforestation is a common measure in soil protection (Romero-Diaz et al., 2010; Jiao et al., 2012). This also applies to the south-eastern part of China, which is known to be a hotspot of biodiversity and especially tree species richness (Barthlott et al., 2005; Bruelheide et al., 2011). Guo et al. (2015) showed that forests in this area experienced the lowest soil loss rates of all land use types. Considering that studies on soil erosion under forest have mostly focused on deforestation (Blanco-Canqui and $\mathrm{Lal}, 2008)$ and that counteracting measures such as afforestation often result in monoculture stands (Puettmann et al., 2009), it appears that the role of tree species richness for soil erosion has been largely disregarded. Zhou et al. (2002) and Tsujimura et al. (2006) demonstrated that tree monocultures have only limited mitigation potential for soil losses, but further research is scarce. Nevertheless, there is growing evidence that a higher species richness can reduce soil erosion (Körner and Spehn, 2002). Bautista et al. (2007) pointed out that an increase in functional diversity within a perennial vegetation cover decreased soil losses in a semiarid Mediterranean landscape. Pohl et al. (2009) showed that an increase in the diversity of root types led to higher soil stability on an alpine grassy hillslope, and most recently Berendse et al. (2015) found that a loss of grass species diversity reduced erosion resistance on a dike slope.

Conceivable mechanisms underlying positive species richness effects on soil erosion are that vegetation cover with a high number of species includes a high number of plant functional groups which complement one another. Thus, they are more effective in controlling erosion processes than vegetative cover with few species (Pohl et al., 2012). For example, high tree species richness can result in an increased stratification of canopy layers (Lang et al., 2010) and a higher total canopy cover (Lang et al., 2012). In addition, a highly diverse structure within the leaf litter layer on the forest floor seems to improve its protective effect (Martin et al., 2010). Further research on the influence of tree species richness on erosion control appears to be necessary, but the complex system of interacting functional groups within the vegetation cover is also of great interest.

Vegetation cover is generally considered a key factor for the occurrence and extent of soil erosion (Thornes, 1990; Hupp et al., 1995; Morgan, 2005). A leaf litter layer on the forest floor, for example, protects the soil from direct raindrop impact and modifies the water flow and storage capacities at the soil surface (Kim et al., 2014). Moreover, forests can provide a multistorey canopy layer which largely influences rain throughfall patterns and leads to the capture of raindrops as well as the storage of water within the tree crown (Puigdefábregas, 2005). Nevertheless, large drops can be formed at leaf apexes of tall trees (Geißler et al., 2012a) and thus may increase the kinetic energy of throughfall in older forest stands by a factor of up to 2 to 3 compared to open fields (Nanko et al., 2008, 2015). This leads to considerable soil loss if the forest floor is unprotected, which may be the case if protective layers diminish, e.g. under shady conditions (Onda et al., 2010) or fast decomposition (Razafindrabe et al., 2010). While the effects of soil surface cover on soil erosion are well studied (Thornes, 1990; Blanco-Canqui and Lal, 2008), much less is known about the influence of species-specific functional traits of the tree layer such as crown or stem characteristics (Lavorel and Garnier, 2002; Guerrero-Campo et al., 2008). Moreover, most research on the latter aspects was performed in old, full-grown forests (e.g. Zhou et al., 2002; Nanko et al., 2008; Geißler et al., 2012a), whereas forests at an early successional stage are rarely mentioned. In these young forests, tree heights are lower than at later stages, but structural and spatial complexity is high and species-specific growth rates differ considerably (Swanson et al., 2011). It is assumed that these speciesspecific differences in structure and growth will influence soil erosion rates.

This research focused on the influence of tree species, tree species richness and species-specific functional traits on interrill erosion in young forests, when a leaf litter cover is not present. Testing for these effects on soil erosion requires a common garden situation, in which confounding factors such as different tree ages and sizes, inclination or soil conditions can be monitored in detail. These requirements were met in the forest-biodiversity-ecosystem-functioning experiment in subtropical China (BEF China; cf. Bruelheide et al., 2014). Within this experiment, 170 micro-scale run-off plots were established in a randomly dispersed and replicated design. Thereby, the following hypotheses were postulated:

1. Increasing tree species richness decreases interrill erosion rates.

2. Tree species differ in their impact on interrill erosion rates.

3. The effects of different tree species on interrill erosion rates can be explained by species-specific functional traits.

\section{Methodology}

\subsection{Study site and experimental design}

The study was conducted in Xingangshan, Jiangxi Province, PR China $\left(29^{\circ} 06.450^{\prime} \mathrm{N}, 117^{\circ} 55.450^{\prime} \mathrm{E}\right)$ at the experimental sites A and B of the BEF China project (Bruelheide et al., 2014). Together, both sites comprise an area of about 50 ha in a mountainous landscape with an elevation range of $100 \mathrm{~m}$ to $265 \mathrm{~m}$ a.s.l. Slopes range from 15 to $41^{\circ}$. The bedrock of the 
experimental site consists of non-calcareous slates with varying sand and silt contents and is interspersed by siliceous-rich joints. Prevailing soil types are Cambisols with Anthrosols in downslope positions and Gleysols in valleys (cf. IUSS, 2006) covering saprolites. Soil bulk density is low $\left(0.98 \mathrm{~g} \mathrm{~cm}^{-3}\right)$ and soil reaction acidic (mean $\mathrm{pH}$ in $\mathrm{KCl} 3.68$ ). Soil texture ranges from silt loam to silty clay loam. The climate in Xingangshan is humid and subtropical and ranked as Cwa after the Köppen-Geiger classification. It is characterized by an annual average temperature of $17.4^{\circ} \mathrm{C}$ and a mean annual rainfall of $1635 \mathrm{~mm}$ (Goebes et al., 2015b).

The experimental area has been used as a commercial forest plantation (Cunninghamia lanceolata and Pinus massoniana) until 2007. It was clear-cut and replanted in 2009-2010 following an experimental-plot-based design with different extinction scenarios (Bruelheide et al., 2014). The experimental site represented an early successional stage with tree ages from 4 to 5 years at the time of measurements. Trees were planted randomly in different species richness levels with a planting distance of $1.29 \mathrm{~m}$, following a broken-stick design. This study focused on the very intensively studied plots (VIPs; cf. Bruelheide et al., 2014) of which 34 were used (Table 1). The selected set comprised a bare-ground feature $(4 \times \operatorname{div} 0)$ and four levels of tree species richness $(20 \times \operatorname{div} 1,4 \times \operatorname{div} 8,4 \times \operatorname{div} 16$ and $2 \times \operatorname{div} 24)$ with a total of 26 tree species, 6 of which only appeared in mixtures (Table 2). Monocultures with tree heights lower than $1 \mathrm{~m}$ or crown covers of less than $10 \%$ were excluded before the analysis.

\subsection{Erosion measurements}

To determine sediment delivery (as initial interrill erosion) and surface run-off volume, micro-scale run-off plots (ROPs, $0.4 \mathrm{~m} \times 0.4 \mathrm{~m}$ ) were used (cf. Seitz et al., 2015; without fauna treatment). Each ROP was connected to a $20 \mathrm{~L}$ reservoir and a rainfall gauge was placed next to it (Fig. 1). All 34 VIPs were equipped with five ROPs each, resulting in a total number of 170 ROPs. Within each VIP, areas of $220 \mathrm{~m}^{2}$ were sectioned for ROP measurements to avoid interferences with other BEF China experiments. The selected areas were representative of the range of surface properties in the plot, and the ROPs were placed randomly therein. All leaf litter was removed from the ROPs prior to measurements. The ROPs were operated in May and June 2013 during the rainy season. Run-off volume and rainfall amount were determined in situ and sediment was assessed after sampling by drying at $40^{\circ} \mathrm{C}$ and weighing. The capacity of the reservoirs was not exceeded in any rainfall event.

At each ROP, tree crown cover, leaf area index (LAI), soil surface cover, slope and rainfall amount were measured. Crown cover and LAI were determined using a fish-eye camera system (Nikon D100 with Nikon AF G DX $180^{\circ}$ ) and the HemiView V.8 software (Delta-T devices, Cambridge, UK) adjusted to the canopy area vertically above the ROP.

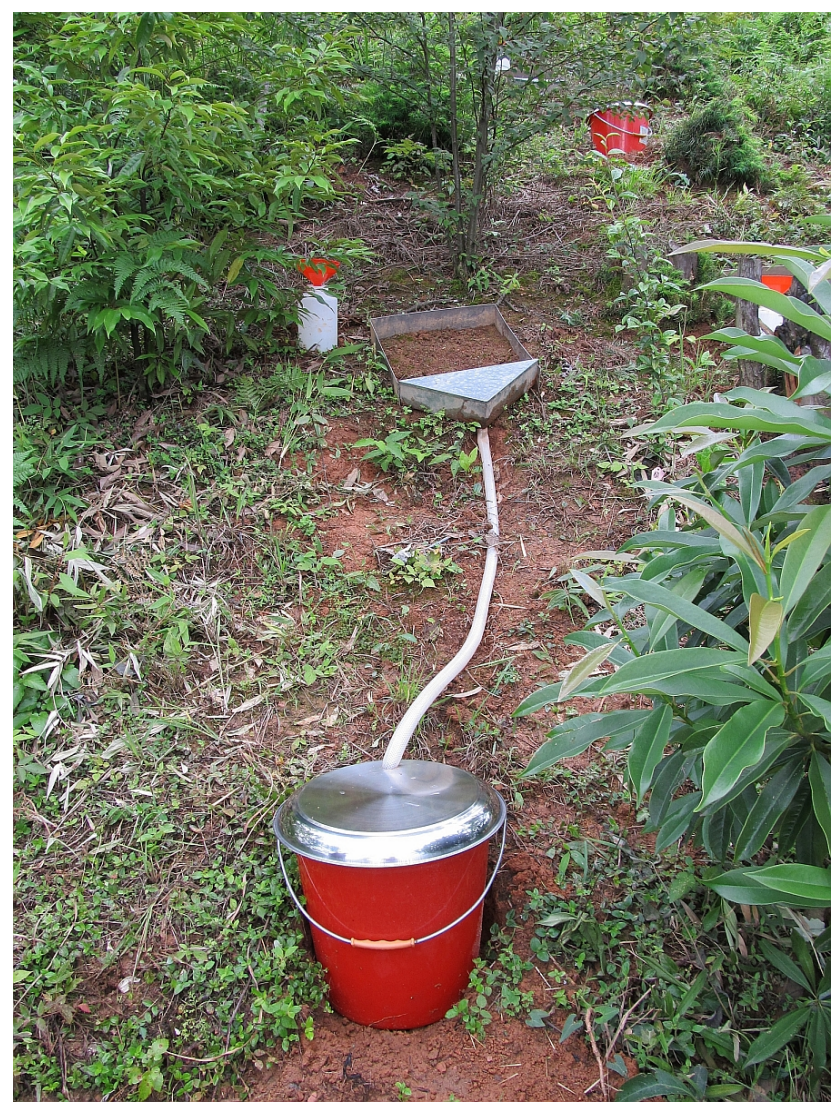

Figure 1. Measurement set-up showing a run-off plot (ROP, $0.4 \mathrm{~m} \times 0.4 \mathrm{~m}$ ) with reservoir and rainfall gauge at the experimental site in Xingangshan, Jiangxi Province, PR China.

Soil surface cover was measured photogrammetrically (grid quadrat method with GIMP 2.8) and separated into organic and inorganic cover by colour distinction. Slope was measured with an inclinometer. The rainfall amount at each ROP was determined by rainfall gauges (see above). At each VIP, total tree height, stem diameter at $5 \mathrm{~cm}$ above ground (hereafter, stem diameter) and crown width were measured and calculated as the mean of 36 tree individuals per VIP ( $\mathrm{Li}$ et al., 2014). Additionally, soil organic matter (SOM) was identified for each VIP $(5 \mathrm{~cm}$ depth, nine replicates) by measuring total organic carbon with a Vario EL III elemental analyser (Elementar, Hanau, Germany) and multiplying it by the conversion factor 2 (Pribyl, 2010). Tree species richness was known from the VIP set-up.

\subsection{Rainfall patterns}

Weather conditions were recorded by an on-site climate station (ecoTech data logger with Vaisala weather transmitter and ecoTech tipping bucket balance) at 5 min intervals. In 2013, the total precipitation in the study area was $1205 \mathrm{~mm}$ and lower than the mean of the preceding 3 years $(1635 \mathrm{~mm})$. In May and June, 10 rainfall events were captured with ROP 
Table 1. Mean characteristics of the 34 selected very intensively studied plots (VIPs) in 2013 in the BEF China experiment, Xingangshan, Jiangxi Province, PR China.

\begin{tabular}{|c|c|c|c|c|c|c|c|c|c|}
\hline $\begin{array}{l}\text { VIP } \\
\text { no. }\end{array}$ & $\begin{array}{l}\text { Species } \\
\text { number }\end{array}$ & $\begin{array}{r}\text { Crown } \\
\text { cover } \\
(\%)\end{array}$ & $\begin{array}{r}\text { Leaf } \\
\text { area } \\
\text { index }\end{array}$ & $\begin{array}{r}\text { Tree } \\
\text { height } \\
(\mathrm{m})\end{array}$ & $\begin{array}{r}\text { Stem } \\
\text { diameter } \\
(\mathrm{m})\end{array}$ & $\begin{array}{r}\text { Crown } \\
\text { width } \\
(\mathrm{m})\end{array}$ & $\begin{array}{r}\text { Slope } \\
\left({ }^{\circ}\right)\end{array}$ & $\begin{array}{r}\text { Surface } \\
\text { cover } \\
(\%)\end{array}$ & $\begin{array}{r}\text { Soil } \\
\text { organic } \\
\text { matter }(\%)\end{array}$ \\
\hline F27 & 0 & - & - & - & - & - & 26 & 10 & 5.4 \\
\hline $\mathrm{H} 28$ & 0 & - & - & - & - & - & 34 & 15 & 5.9 \\
\hline L20 & 0 & - & - & - & - & - & 24 & 11 & 8.3 \\
\hline Q23 & 0 & - & - & - & - & - & 15 & 23 & 6.2 \\
\hline E31 & 1 & 16 & 0.19 & 1.25 & 0.02 & 0.80 & 22 & 39 & 5.5 \\
\hline E33 & 1 & 20 & 0.28 & 2.32 & 0.03 & 1.09 & 19 & 41 & 4.4 \\
\hline E34 & 1 & 87 & 2.07 & 5.96 & 0.06 & 3.00 & 21 & 11 & 6.1 \\
\hline $\mathrm{I} 25$ & 1 & 11 & 0.14 & 1.62 & 0.04 & 0.96 & 29 & 11 & 5.3 \\
\hline $\mathrm{I} 28$ & 1 & 15 & 0.19 & 2.28 & 0.04 & 1.64 & 26 & 32 & 8.9 \\
\hline K19 & 1 & 93 & 4.20 & 3.67 & 0.06 & 1.66 & 24 & 32 & 8.3 \\
\hline L11 & 1 & 10 & 0.11 & 1.36 & 0.02 & 0.90 & 28 & 19 & 7.1 \\
\hline M7 & 1 & 46 & 0.62 & 2.01 & 0.03 & 1.28 & 31 & 8 & 6.8 \\
\hline N05 & 1 & 9 & 0.10 & 1.16 & 0.03 & 0.40 & 32 & 0 & 6.3 \\
\hline N11 & 1 & 42 & 0.55 & 1.68 & 0.03 & 0.96 & 26 & 32 & 9.7 \\
\hline N13 & 1 & 13 & 0.13 & 3.05 & 0.05 & 1.56 & 31 & 30 & 7.9 \\
\hline N17 & 1 & 47 & 0.85 & 1.82 & 0.03 & 1.62 & 28 & 1 & 7.9 \\
\hline $\mathrm{O} 27$ & 1 & 90 & 2.27 & 7.40 & 0.07 & 2.21 & 21 & 9 & 5.7 \\
\hline Q13 & 1 & 19 & 0.30 & 1.97 & 0.03 & 1.15 & 30 & 1 & 6.9 \\
\hline Q27 & 1 & 24 & 0.47 & 3.37 & 0.04 & 1.37 & 35 & 3 & 6.0 \\
\hline R14 & 1 & 51 & 0.93 & 1.25 & 0.02 & 0.64 & 30 & 1 & 7.6 \\
\hline R29 & 1 & 21 & 0.24 & 1.44 & 0.03 & 0.95 & 33 & 18 & 6.3 \\
\hline U16 & 1 & 10 & 0.14 & 2.26 & 0.05 & 1.10 & 20 & 5 & 4.7 \\
\hline V24 & 1 & 64 & 1.02 & 2.19 & 0.05 & 0.96 & 32 & 11 & 4.3 \\
\hline W11 & 1 & 34 & 0.43 & 2.61 & 0.06 & 1.13 & 19 & 6 & 6.0 \\
\hline J29 & 8 & 29 & 0.34 & 1.47 & 0.05 & 0.76 & 31 & 13 & 9.4 \\
\hline Q17 & 8 & 30 & 0.37 & 1.74 & 0.05 & 1.05 & 22 & 6 & 5.2 \\
\hline S10 & 8 & 99 & 5.35 & 3.85 & 0.05 & 2.19 & 36 & 29 & 4.2 \\
\hline $\mathrm{T} 15$ & 8 & 31 & 0.38 & 1.96 & 0.03 & 1.15 & 30 & 20 & 4.8 \\
\hline M22 & 16 & 87 & 2.06 & 4.35 & 0.06 & 2.09 & 23 & 44 & 7.2 \\
\hline $\mathrm{S} 22$ & 16 & 34 & 0.42 & 1.07 & 0.04 & 0.56 & 33 & 24 & 6.6 \\
\hline U10 & 16 & 48 & 0.56 & 3.06 & 0.06 & 1.56 & 22 & 10 & 6.0 \\
\hline V27 & 16 & 42 & 0.54 & 2.09 & 0.05 & 0.99 & 34 & 9 & 6.4 \\
\hline N09 & 24 & 11 & 0.17 & 2.08 & 0.04 & 1.29 & 33 & 38 & 8.8 \\
\hline R30 & 24 & 37 & 0.46 & 1.67 & 0.04 & 0.97 & 27 & 19 & 4.2 \\
\hline
\end{tabular}

measurements in the study area. Events were determined by breaks in rainfall of at least $6 \mathrm{~h}$. Four of these events (E1E4) were strong enough to trigger soil erosion (out of 33 events over the entire year of 2013) following Wischmeier and Smith (1978), who used an event threshold of $12.7 \mathrm{~mm}$. The total rainfall amount from May to June was $185 \mathrm{~mm}$, of which $135 \mathrm{~mm}$ fell during erosive rainfall events. The mean and peak intensities as well as the total rainfall amount (except for E4) increased from May to June (Table 3), reflecting a growing monsoon influence from the beginning to the middle of summer.

\subsection{Statistical analysis}

Linear mixed effects models with restricted maximum likelihood were used with R 3.0.2 (R Core Team, 2013) and "ImerTest" (Kuznetsova et al., 2014) to investigate the influences on sediment delivery. Models were fitted with crown cover, leaf area index, tree height, stem diameter, crown width, slope, surface cover, SOM, amount of precipitation and tree species richness as fixed effects. As random effects, precipitation event (E1-E4) nested in plot, tree composition (species pool), site (A or B) and ROP nested in plot were used. Nesting was introduced to avoid pseudoreplication considering the degrees of freedom in our hypotheses tests. Tree and crown characteristics were fitted one after the other because they were highly correlated. Contrasts 
Table 2. Twenty-six selected tree species used in the experiment according to the Flora of China web page (http://www.efloras.org). Asterisks (*) mark species which only appear in mixtures.

\begin{tabular}{|c|c|}
\hline \multicolumn{2}{|l|}{ Species name and author } \\
\hline Ailanthus altissima (Miller) Swingle & Koelreuteria bipinnata Franch. \\
\hline Alniphyllum fortunei (Hemsl.) Makino & Liquidambar formosana Hance \\
\hline Betula luminifera $\mathrm{H}$. Winkl. & Lithocarpus glaber (Thunb.) Nakai \\
\hline Castanea henryi (Skan) Rehd. et Wils. & Machilus grijsii Hance* \\
\hline Castanopsis fargesii Franch. & Machilus leptophylla Hand.-Mazz.* \\
\hline Castanopsis sclerophylla (Lindl.) Schott. & Magnolia yuyuanensis $\mathrm{Hu}$ \\
\hline Celtis biondii Nakai* & Nyssa sinensis Oliver* \\
\hline Choerospondias axillaris (Roxb.) Burtt et Hill. & Rhus chinensis Mill. \\
\hline Cyclobalanopsis glauca (Thunb.) Oerst. & Sapindus saponaria Gaertn. \\
\hline Elaeocarpus chinensis Gardn. et Chanp. & Schima superba Gardn. et Champ. \\
\hline Elaeocarpus glabripetalus Merr. & Triadica sebifera (L.) Roxb. \\
\hline Elaeocarpus japonicus Sieb. et Zucc. & Quercus fabri Hance \\
\hline Idesia polycarpa Maxim.* & Quercus phillyreoides A. Gray* \\
\hline
\end{tabular}

Table 3. Characteristics of rainfall events considered erosive (threshold $12.7 \mathrm{~mm}$ ) in Xingangshan, Jiangxi Province, PR China in May and June 2013.

\begin{tabular}{lrrr}
\hline Event & $\begin{array}{r}\text { Mean intensity } \\
\left(\mathrm{mm} \mathrm{h}^{-1}\right)\end{array}$ & $\begin{array}{r}\text { Peak intensity } \\
\left(\mathrm{mm} \mathrm{h}^{-1}\right)\end{array}$ & $\begin{array}{r}\text { Total rainfall } \\
\text { amount }(\mathrm{mm})\end{array}$ \\
\hline E1 & 1.38 & 11.4 & 20.29 \\
E2 & 2.34 & 23.04 & 25.74 \\
E3 & 3.19 & 45.24 & 54.42 \\
E4 & 14.60 & 83.04 & 34.01 \\
\hline
\end{tabular}

between diversity levels (div0 to div1-div24, div1 to div8div24) were introduced to quantify the effects of bare plots vs. tree plots and tree monocultures vs. mixtures, respectively. The effect of individual tree species (div1) was tested separately against the mean sediment delivery using crown cover, slope, surface cover, SOM and amount of precipitation as fixed factors and site and ROP nested in plot as random factors $(n=200)$. The maximum-likelihood approach was used to obtain model simplification by stepwise backward selection, eliminating the least significant variable except for tree species richness. If multicolinearity was detected (Spearman $\rho>0.7$ ), co-variables were omitted. All variables were continuous and scaled, so model estimates could be compared. The data was log-transformed and the residuals did not show any deviation from normality. Hypotheses were tested with an analysis of variance (ANOVA) type 3 with a Satterthwaite approximation for degrees of freedom, and $p$ values were obtained by likelihood ratio tests.

\section{Results}

The results were based on 334 ROP measurements out of a total of 378 measurements. Invalid measurements were caused by technical constraints such as plugged tubes or top- pled rainfall gauges. Sediment delivery over all VIPs and rainfall events ranged from 14 to $920 \mathrm{~g} \mathrm{~m}^{-2}$ per ROP. Eventbased mean sediment delivery increased with peak intensity from precipitation event 1 to event 4 with $42 \mathrm{~g} \mathrm{~m}^{-2}$ (E1), $85 \mathrm{~g} \mathrm{~m}^{-2}$ (E2), $120 \mathrm{~g} \mathrm{~m}^{-2}$ (E3) and $283 \mathrm{~g} \mathrm{~m}^{-2}$ (E4). The interrill soil erosion rate determined by micro-scale ROPs and extrapolated for all erosive precipitation events $(>12.7 \mathrm{~mm}$ rainfall amount) in 2013 was estimated to be $47.5 \mathrm{Mg} \mathrm{ha}^{-1}$.

\subsection{Species richness effects on interrill erosion processes}

Tree species richness did not affect sediment delivery or runoff volume (Table 4 and Fig. 2). Sediment delivery and runoff volume did not differ between bare plots (div0) and plots with trees (div1-div24) nor between monocultures (div1) and species mixtures (div8, div16, div24). The standard deviations of sediment delivery $\left(\mathrm{g} \mathrm{m}^{-2}\right)$ and run-off volume $\left(\mathrm{L} \mathrm{m}^{-2}\right)$ in relation to diversity levels were high (Fig. 2 and Table 5). Mean crown cover in mixed stands was $44 \%$ and mean tree height was $2.30 \mathrm{~m}$ compared to monocultures with $22 \%$ and $1.63 \mathrm{~m}$. In this experiment tree height in mixed stands was not lower than $1.07 \mathrm{~m}$ and crown cover achieved at least $29 \%$.

\subsection{Species effects on interrill erosion processes}

Individual tree species in monocultures showed significant differences in sediment delivery (Fig. 3) ranging from $90 \mathrm{~g} \mathrm{~m}^{-2}$ (L. formosana) to $560 \mathrm{~g} \mathrm{~m}^{-2}$ (Ch. axillaris) per rainfall event.

The mean sediment delivery is $199 \mathrm{~g} \mathrm{~m}^{-2}$ across all tree monocultures, among which Ch. axillaris, $C$. glauca, $R$. chinensis and K. bipinnata showed above average and $M$. yuyuanensis, L. glaber, E. chinensis and L. formosana below average sediment delivery. The growth characteristics of these 
Table 4. Results of the basic linear mixed effect model for sediment delivery ${ }^{\mathrm{a}}: p<0.001 ;{ }^{\mathrm{b}}: p<0.01 ;{ }^{\mathrm{c}}: p<0.05$; ${ }^{\mathrm{d}}: p<0.1 ; \mathrm{n} . \mathrm{s}$. : not significant; $n=334$ ). Crown cover was highly correlated with the four other vegetation characteristics, and, therefore, they have been exchanged and fitted in separate models ("denDF": denominated degrees of freed; "F": $F$ value; "Pr": probability).

\begin{tabular}{llrrrr}
\hline & denDF & F & Pr & Estimates \\
\hline Fixed & Run-off volume & 204 & 49.0 & $<0.001^{\mathrm{a}}$ & 0.33 \\
effects & Crown cover & 120 & 7.25 & $0.008^{\mathrm{b}}$ & $(-) 0.18$ \\
& Slope & 141 & 1.33 & $0.250 \mathrm{n} . \mathrm{s}$. & 0.05 \\
& Surface cover & 140 & 56.1 & $<0.001^{\mathrm{a}}$ & $(-) 0.46$ \\
& Soil organic matter & 42 & 5.61 & $0.022^{\mathrm{c}}$ & $(-) 0.07$ \\
& Precipitation & 70 & 0.12 & $0.733 \mathrm{n} . \mathrm{s}$. & $(-) 0.01$ \\
& Tree species richness & 25 & 0.30 & 0.589 n.s. & 0.05 \\
\hline \multirow{2}{*}{ Random } & Precipitation event: plot & 0.204 & 0.042 & & \\
& Tree composition & 0.332 & 0.110 & & \\
& Site & 0.577 & 0.333 & & \\
& Plot: ROP & 0.503 & 0.253 & & \\
\hline & Vegetation characteristics fitted in exchange for crown cover & \\
\hline & Leaf area index & 95 & 5.16 & $0.026^{\mathrm{c}}$ & $(-) 0.17$ \\
& Tree height & 31 & 3.58 & $0.069^{\mathrm{d}}$ & 0.10 \\
& Tree stem diameter & 30 & 0.20 & $0.661 \mathrm{n} . \mathrm{s}$. & $(-) 0.04$ \\
& Tree crown width & 31 & 0.79 & 0.383 n.s. & $(-) 0.08$ \\
\hline
\end{tabular}

Table 5. Mean sediment delivery in $\mathrm{g} \mathrm{m}^{-2}$ and surface run-off volume in $\mathrm{L} \mathrm{m}^{-2}$ (standard deviation in brackets; $n=334$ ) for tree species richness in May and June 2013.

\begin{tabular}{lrrrrrrr}
\hline & Diversity & Diversity & Diversity & Diversity & Diversity & Diversity & Diversity \\
& $0-24$ & 0 & $1-24$ & 1 & 8 & 16 & 24 \\
\hline Sediment & 199 & 361 & 188 & 202 & 103 & 135 & 204 \\
delivery & $(106)$ & $(187)$ & $(90)$ & $(105)$ & $(57)$ & $(123)$ & $(107)$ \\
\hline Run-off & 32.6 & 47.8 & 29.8 & 31.9 & 27.5 & 22.5 & 30.2 \\
volume & $(21.4)$ & $(32.1)$ & $(18.5)$ & $(20.9)$ & $(14.5)$ & $(15.7)$ & $(19.7)$ \\
\hline
\end{tabular}

tree species differed considerably between the species (Table 6).

\subsection{Effects of species-specific functional traits and site characteristics}

Crown cover was highly correlated with LAI, tree height, stem diameter and crown width $(r=0.82,0.80,0.75,0.77$, respectively). Crown cover $(p<0.01)$ and LAI $(p<0.05)$ negatively affected sediment delivery. Tree height marginally positively affected sediment delivery $(p<0.1)$, whereas stem diameter and crown width had no influence (Fig. 4, Table 4). The soil surface cover consisted of stones and biological soil crusts and covered on average one fifth of the ROP surfaces in May and June 2013. It affected sediment delivery negatively $(p<0.001)$. Sediment delivery decreased with increasing SOM content $(p<0.05)$. An indication of hydrophobic surface coatings and a significant role of water repellency could not be found. The mean slope angle did not affect sediment delivery (Fig. 4, Table 4).

Growth characteristics were highly variable between tree species, which was reflected by high standard deviations of the respective variables. In contrast, site characteristics of these plots showed a low variability (Table 7).

\section{Discussion}

The soil loss rate determined by micro-scale ROPs (47.5 $\mathrm{Mg} \mathrm{ha}^{-1} \mathrm{a}^{-1}$ ) for 2013 was considerably higher than the average rate Guo et al. (2015) recently calculated for southern China (approx. $20 \mathrm{Mg} \mathrm{ha}^{-1} \mathrm{a}^{-1}$ ) in a study based on small-scale and field ROPs. Pimentel (1993) reported an average rate of $36 \mathrm{Mg} \mathrm{ha}^{-1} \mathrm{a}^{-1}$ for the same area. Zheng et al. (2007) stated an average soil loss rate of $31 \mathrm{Mg} \mathrm{ha}^{-1} \mathrm{a}^{-1}$ determined with ${ }^{137} \mathrm{Cs} /{ }^{210} \mathrm{~Pb}$ tracing techniques in Sichuan Province, PR China. These different rates are due to different 
Table 6. Sediment delivery and growth characteristics (means) of tree species with significant differences in delivery at the experimental site in Xingangshan, Jiangxi Province, PR China.

\begin{tabular}{lrrrrrr}
\hline & $\begin{array}{r}\text { Sediment } \\
\text { delivery } \\
\left(\mathrm{g} \mathrm{m}^{-2}\right)\end{array}$ & $\begin{array}{r}\text { Crown } \\
\text { cover } \\
(\%)\end{array}$ & $\begin{array}{r}\text { Leaf area } \\
\text { index }\end{array}$ & $\begin{array}{r}\text { Tree } \\
\text { height } \\
(\mathrm{m})\end{array}$ & $\begin{array}{r}\text { Stem } \\
\text { diameter } \\
(\mathrm{m})\end{array}$ & $\begin{array}{r}\text { Crown } \\
\text { width } \\
(\mathrm{m})\end{array}$ \\
\hline Mean & 199 & 32 & 0.75 & 1.84 & 0.03 & 0.94 \\
Monocultures & 202 & 22 & 0.63 & 1.63 & 0.02 & 0.78 \\
Tree mixtures & 135 & 44 & 1.18 & 2.30 & 0.04 & 1.26 \\
\hline Ch. axillaris & 566 & 90 & 2.27 & 7.40 & 0.07 & 2.21 \\
C. glauca & 556 & 51 & 0.93 & 1.25 & 0.02 & 0.65 \\
R. chinensis & 502 & 47 & 0.85 & 1.82 & 0.03 & 1.62 \\
K. bipinnata & 378 & 19 & 0.30 & 1.97 & 0.03 & 1.15 \\
\hline M. yuyuanensis & 64 & 11 & 0.14 & 1.62 & 0.04 & 0.95 \\
L. glaber & 114 & 20 & 0.28 & 2.32 & 0.03 & 1.09 \\
E. chinensis & 66 & 64 & 1.02 & 2.19 & 0.05 & 0.97 \\
L. formosana & 91 & 15 & 0.19 & 2.28 & 0.04 & 1.64 \\
\hline
\end{tabular}
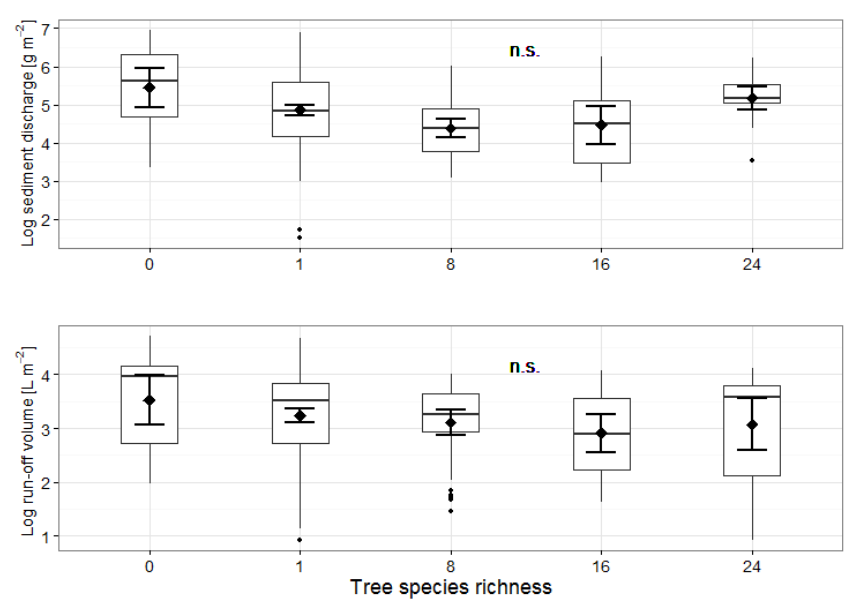

Figure 2. Sediment delivery and run-off volume at five diversity levels based on four rainfall events in May and June 2013 in Xingangshan, Jiangxi Province, PR China (n.s.: not significant; $n=334$ ). Horizontal line within box plot represents median and diamond represents mean.

land use types and measurement techniques but also to the scale-dependent nature of soil erosion and run-off generation (cf. Boix-Fayos et al., 2006; Cantón et al., 2011). The microscale ROPs used in this study quantified interrill wash and sediment detachment by raindrop impact (Agassi and Bradford, 1999; cf. Cerdà, 1999; Parsons et al., 2003; GarcíaOrenes et al., 2012). However, a significant amount of erosion occurs in the rilling system, and the influence of interrill processes on soil erosion varies greatly (Govers and Poesen, 1988). Nevertheless, Mutchler et al. (1994) stated that microscale ROPs are suitable to study basic aspects of soil erosion, and, furthermore, these measurements are particularly appro-
Table 7. Growth characteristics of the 20 tree species in monocultures analysed and associated plot characteristics in Xingangshan, Jiangxi Province, PR China (mean, standard deviation (SD), maximum $(\max )$ and minimum $(\min ))$.

\begin{tabular}{lrrrr}
\hline & Mean & SD & Max & Min \\
\hline Vegetation & & & & \\
\hline Crown cover (\%) & 37 & 31 & 93 & 1 \\
Leaf area index & 0.88 & 1.08 & 4.20 & 0.03 \\
Tree height (m) & 2.55 & 1.64 & 7.40 & 1.16 \\
Stem diameter (m) & 0.04 & 0.02 & 0.07 & 0.02 \\
Crown width (m) & 1.25 & 0.61 & 3.00 & 0.40 \\
\hline Site & & & & \\
\hline Soil surface cover (\%) & 16 & 14 & 55 & 1 \\
Soil organic matter $(\%)$ & 6.4 & 1.4 & 9.4 & 4.3 \\
Slope $\left({ }^{\circ}\right)$ & 27 & 5 & 35 & 19 \\
\hline
\end{tabular}

Crown cover: proportion of soil surface area covered by crowns of live trees $(\%)$; leaf area index: one-sided green leaf area per unit soil surface area (dimensionless); tree height: distance from stem base to apical meristem (m); stem diameter: cross-section dimension of the tree stem at $5 \mathrm{~cm}$ above ground $(\mathrm{m})$; crown width: length of longest spread from edge to edge across the crown $(\mathrm{m})$; soil surface cover: proportion of soil surface area covered by stones, biocrusts and litter $(\%)$; soil organic matter: fraction of organic carbon containing substances in the soil $(\%)$; slope: inclination $\left({ }^{\circ}\right)$.

priate when defining impacts of vegetation through an interplot comparison (Wainwright et al., 2000).

\subsection{Species richness effects on interrill erosion processes}

Tree species richness did not affect sediment delivery or run-off volume, and thus the first hypothesis has to be rejected. Nevertheless, a trend of decreasing sediment delivery and run-off volume from diversity level 0 to 8 was visible. 


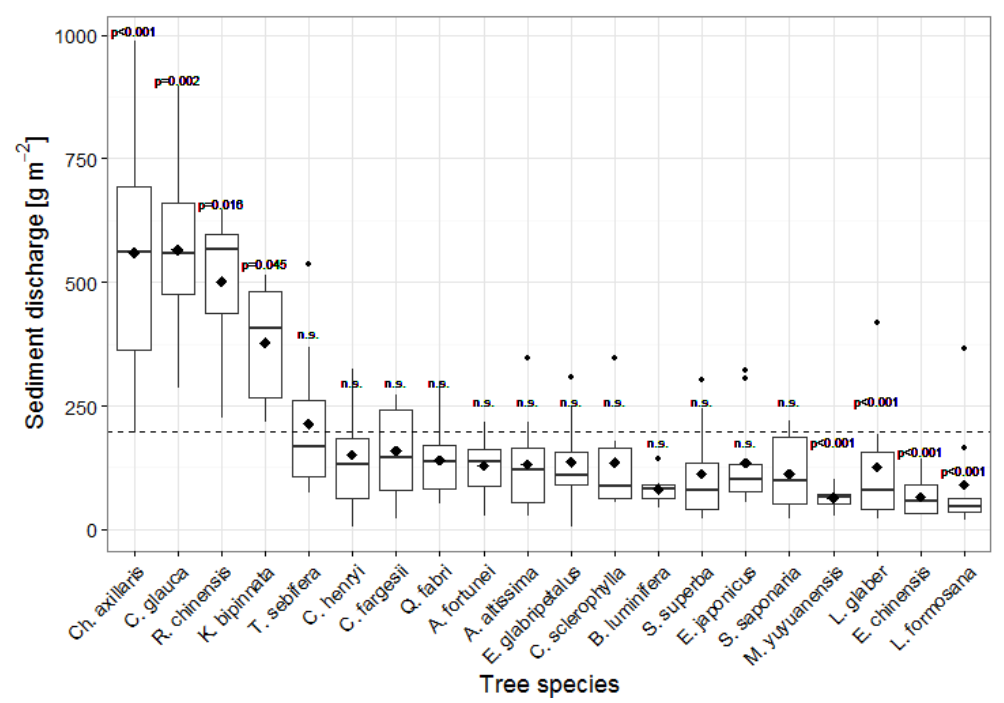

Figure 3. Sediment delivery under 20 tree species in monocultures based on four rainfall events in May and June 2013 in Xingangshan, Jiangxi Province, PR China. Dashed line indicates mean sediment delivery of all 20 species. Horizontal lines within box plot represent medians, and diamonds represent mean values found for a respective species.
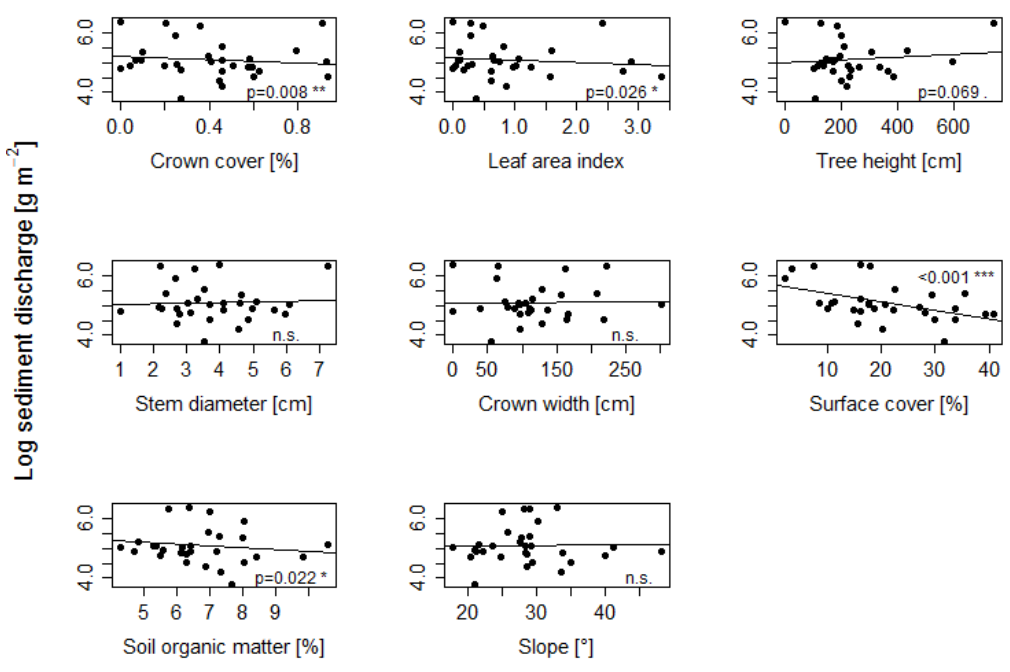

Figure 4. Effects of species-specific functional traits and site characteristics on sediment delivery. Analyses were based on four rainfall events in May and June 2013 in Xingangshan, Jiangxi Province, PR China. Black lines represent linear trends.

However, both parameters were nearly the same at diversity level 1 and 24 and standard deviations were high. In contrast to tree growth patterns in monocultures, which were highly variable, mixed stands indicated a more balanced development (cf. Kelty, 2006). All species mixtures in this experiment ensured a high level of tree height and ground coverage after 4 to 5 years of tree growth, whereas in monocultures the canopy cover was lower and highly tree-speciesspecific. Thus, several monoculture plots were excluded before measurements because some species could not provide enough ground coverage. At the same time, sediment delivery in 8- and 16-species mixtures was lower than in monocultures. Nevertheless, contrasts in the model could not show any statistical difference between monocultures and mixtures or bare and covered plots.

The absence of a species richness effect on interrill erosion is likely attributable to the early successional stage of the forest experiment with low tree ages. Full canopy cover with high stratification and overlap has not yet been developed at the study site and the trees were far from reaching terminal height (Goebes et al., 2015b; Li et al., 2014). It is assumed that these vegetation characteristics will change with increasing tree age and tree species richness may become evident in adult stands. Young trees are functionally more equivalent to one another than older trees (Barnes and Spurr, 1998), and specific crown traits may emerge more distinctly in later suc- 
cessional stages. Geißler et al. (2013) found that the erosion potential was higher in medium and old, full-grown forests than in young forests. This effect is caused by raindrop transformation processes during the canopy passage, resulting in higher throughfall kinetic energy under forest than on fallow land (Geißler et al., 2010) and has only been proved for advanced successional forest stages (Nanko et al., 2008; Geißler et al., 2013). As the experiment progresses and tree height increases, increasing throughfall kinetic energy is expected, which in turn increases the general soil erosion potential if an understorey is missing.

\subsection{Species effects on interrill erosion processes}

Trees in monocultures differed in their impact on interrill erosion and thus hypothesis 2 can be confirmed. In a study on common European tree species, Augusto et al. (2002) showed that the tree species composition of forests has an impact on chemical, physical and biological soil properties. Several studies revealed that individual plants are important for erosion control in arid and semi-arid Mediterranean landscapes (e.g. Bochet et al., 2006; cf. Durán Zuazo and Rodríguez Pleguezuelo, 2008) and Xu et al. (2008) showed that different plant morphologies may control soil loss and improved soil properties in a dry river valley in China.

In this study, four tree species (Ch. axillaris, C. glauca, $R$. chinensis, $K$. bipinnata) seemed to promote interrill erosion rates, whereas another four species (M. yuyuanensis, L. glaber, E. chinensis, L. formosana) showed a mitigating effect on interrill erosion at this initial stage of the forest ecosystem. Thus, a species-specific effect on sediment delivery for this subtropical experimental area can be confirmed. Species-specific effects can result from different throughfall kinetic energy, which was recently shown by Goebes et al. (2015a) at the same study site in China. The effect of throughfall kinetic energy was ascribed to different tree architectural characteristics and leaf traits. The authors found 3 out of 11 tree species to have distinct differences in mean throughfall kinetic energy. Ch. axillaris and $S$. saponaria showed higher values, whereas $S$. superba was characterized by lower values of throughfall kinetic energy. At the experimental site, varying tree species revealed heterogeneous growth patterns, which were caused by speciesspecific growth variation and abiotic site conditions (Li et al., 2014). Ch. axillaris was the tallest tree species with a nearly closed canopy and caused the highest amount of sediment delivery in this study. Raindrops falling from leaves of this species nearly reached terminal velocity and hence throughfall kinetic energy was high (Morgan, 2005; Goebes et al., 2015a). This finding explained the high erosion rates below this fast-growing species. Further stands with significantly higher erosion rates and the four tree species with a mitigating effect on interrill erosion showed lower tree heights and thus lower throughfall kinetic energy. Their effect on sediment delivery has to be explained by further functional traits.

\subsection{Effects of species-specific functional traits and site characteristics}

Tree species differed widely in canopy characteristics and sediment delivery was significantly related to crown cover, LAI and tree height. Therefore, the species-specific effects of interrill erosion can be partially attributed to species-specific functional traits, which confirms hypothesis 3 . The falling velocities of throughfall drops are highly variable under different tree species due to the species-specific growth pattern and crown characteristics (Goebes et al., 2015a). Frasson and Krajewski (2011) showed that the mechanisms of interception are manifold even within a single canopy, and varying canopy levels create different drop size distributions.

Increasing crown cover and LAI were mitigating interrill erosion in this early ecosystem stage. The magnitude of canopy cover determines the proportion of raindrops intercepted (Blanco-Canqui and Lal, 2008), and it has been shown that drop size distributions differ between different canopy species (Nanko et al., 2006). High crown cover and leaf area increase the interception of rain drops and the storage capacity of water in the canopy (Aston, 1979; Geißler et al., 2012a), which can lead to higher stemflow and thus decreasing throughfall (Herwitz, 1987). Nevertheless, Herwitz (1987) also showed that canopy drainage can lead to larger throughfall drops and thus to increasing throughfall kinetic energy depending on the leaf species (Hall and Calder, 1993; Geißler et al., 2012a; Goebes et al., 2015a). In any case, LAI showed a weaker significance than crown cover, probably because many trees had not yet developed a multilayered canopy structure.

It has been shown that tree height is an import factor for sediment detachment under forest (Geißler et al., 2013), mostly due to increasing drop falling heights (Gunn and Kinzer, 1949). As trees had not yet reached adult height (mean height $<2 \mathrm{~m}$ ) in this study, the kinetic energy of raindrops formed at leaf tips was lower than in full-grown tree stands and drops did not reach terminal velocities (Morgan, 2005; Geißler et al., 2013; Goebes et al., 2015a). Therefore, tree height had a weak effect on sediment delivery $(p<0.1)$ in this study and delivery under trees did not exceed sediment delivery on bare ground. Nevertheless, high sediment delivery under $C h$. axillaris, by far the fastest-growing tree in this experiment, showed the potential of high trees to increase soil erosion on uncovered forest floors.

Stem diameter and crown width did not seem to influence erosion processes in early-stage forest ecosystems. Several other tree-related functional traits (Pérez-Harguindeguy et al., 2013) could be used to explain sediment delivery such as branching architecture, specific leaf area and root system morphology. Especially studies on leaf traits (Nanko et al., 2013) as well as belowground stratification (Gyssels et al., 2005; Stokes et al., 2009) showed the potential of these features to influence soil loss and highlighted the complexity of factors mitigating soil erosion in forest ecosystems. 
Results showed that soil surface cover and SOM affect interrill erosion. Even though a leaf litter cover was not present in this experiment, the remaining soil surface cover by stones and biological soil crusts was the most important driver to reduce sediment delivery. This finding underlines the general importance of covered soil surfaces for erosion control (cf. Thornes, 1990; Morgan, 2005) and shows that the protective effect of leaf litter could not only be replaced by soil skeleton but also by topsoil microbial communities in young forest stands. The mitigating effect of leaf litter on soil losses has not been in the focus of this experimental approach, but it is presumed that the fall of leaves even in young forests reduces soil erosion considerably compared to bare land (Blanco-Canqui and Lal, 2008; Seitz et al., 2015). Furthermore, SOM reduced interrill erosion, which could be explained by its ability to bind primary particles into aggregates (Blanco-Canqui and Lal, 2008). If we assume that SOM increases with increasing species richness, as was recently demonstrated in a grassland study by Cong et al. (2014), an indirect effect of biodiversity on soil erosion could be supposed. Finally, slope angle did not affect interrill erosion due to the short plot length that limits run-off velocities (cf. Seitz et al., 2015).

\section{Synthesis and conclusions}

An experiment with 170 micro-scale run-off plots was conducted to investigate the influence of tree species and tree species richness as well as species-specific functional traits on interrill soil erosion processes in a young forest ecosystem. The results led to the following conclusions.

Tree species richness did not affect sediment delivery and run-off volume, although mixed stands showed a more balanced and homogenous vegetation development than monocultures. This finding was ascribed to the young successional stage of the forest experiment. Future research should concentrate on how erosion rates change with increasing stand age. Therefore, long-term monitoring of soil erosion under closing tree canopies is necessary.

This study provided evidence that different tree species affect interrill erosion processes. Different tree morphologies have to be considered when regarding erosion in young forest ecosystems. The appropriate choice of tree species for afforestation as a measure against soil erosion becomes important already at an early successional stage.

Species-specific functional traits and site characteristics affected interrill erosion rates. High crown cover and leaf area index reduced soil erosion, whereas it was slightly increased by increasing tree height. Thus, low tree stands with high canopy cover were effectively counteracting soil loss in initial forest ecosystem. In further studies, a wider range of functional tree traits such as leaf habitus or belowground stratification should be taken into consideration. Moreover, investigations into the influence of biological soil crusts, topsoil microbial communities and their impact on organicmatter accumulation will open the way to new insights on soil erosion processes.

Author contributions. Thomas Scholten, Peter Kühn and Steffen Seitz designed the experiment and Steffen Seitz carried it out. Steffen Seitz, Philipp Goebes and Helge Bruelheide developed the model code and performed the statistics. Ying Li and Werner Härdtle provided data on tree growth and species-specific functional traits. Steffen Seitz prepared the manuscript with contributions from all co-authors.

Acknowledgements. This study was financed by the German Research Foundation (DFG FOR 891/2) in cooperation with the Chinese Academy of Science (CAS). We are grateful to the Sino-German Center for Science Promotion for organising summer schools and providing travel grants (GZ 1146). Thanks go to Chen Lin and Zhiqin Pei for organisation and translation in China, Milan Daus and Kathrin Käppeler for assistance during field work, Bertram Bläschke for the installation of the first ROPs, Shunhe Lian, Yangmeng Liu and Wuchai Liu for technical support in China and finally to our numerous, tireless Chinese field workers.

Edited by: P. Fiener

\section{References}

Agassi, M. and Bradford, J.: Methodologies for interrill soil erosion studies, Soil Till. Res., 49, 277-287, doi:10.1016/S01671987(98)00182-2, 1999.

Aston, A. R.: Rainfall interception by eight small trees, J. Hydrol., 42, 383-396, doi:10.1016/0022-1694(79)90057-X, 1979.

Augusto, L., Ranger, J., Binkley, D., and Rothe, A.: Impact of several common tree species of European temperate forests on soil fertility, Ann. For. Sci., 59, 233-253, doi:10.1051/forest:2002020, 2002.

Barnes, B. V. and Spurr, S. H.: Forest ecology, 4th Edn., Wiley, New York, xviii, 774, 1998.

Barthlott, W., Mutke, J., Rafiqpoor, M. D., Kier, G., and Kreft, H.: Global centres of vascular plant diversity, Nova Acta Leopoldina, 92, 61-83, 2005.

Bautista, S., Mayor, Á. G., Bourakhouadar, J., and Bellot, J.: Plant Spatial Pattern Predicts Hillslope Runoff and Erosion in a Semiarid Mediterranean Landscape, Ecosystems, 10, 987-998, doi:10.1007/s10021-007-9074-3, 2007.

Berendse, F., van Ruijven, J., Jongejans, E., and Keesstra, S.: Loss of Plant Species Diversity Reduces Soil Erosion Resistance, Ecosystems, 18, 881-888, doi:10.1007/s10021-015-98696, 2015.

Blanco-Canqui, H. and Lal, R.: Principles of soil conservation and management, Springer, Dordrecht, London, 1 online resource, 2008.

Bochet, E., Poesen, J., and Rubio, J. L.: Runoff and soil loss under individual plants of a semi-arid Mediterranean shrubland: influence of plant morphology and rainfall intensity, Earth Surf. Proc. Land., 31, 536-549, doi:10.1002/esp.1351, 2006. 
Boix-Fayos, C., Martínez-Mena, M., Arnau-Rosalén, E., CalvoCases, A., Castillo, V., and Albaladejo, J.: Measuring soil erosion by field plots: Understanding the sources of variation, Earth-Sci. Rev., 78, 267-285, doi:10.1016/j.earscirev.2006.05.005, 2006.

Brevik, E. C., Cerdà, A., Mataix-Solera, J., Pereg, L., Quinton, J. N., Six, J., and Van Oost, K.: The interdisciplinary nature of SOIL, SOIL, 1, 117-129, doi:10.5194/soil-1-117-2015, 2015.

Bruelheide, H., Böhnke, M., Both, S., Fang, T., Assmann, T., Baruffol, M., Bauhus, J., Buscot, F., Chen, X.-Y., Ding, B.-Y., Durka, W., Erfmeier, A., Fischer, M., Geißler, C., Guo, D., Guo, L.-D., Härdtle, W., He, J.-S., Hector, A., Kröber, W., Kühn, P., Lang, A. C., Nadrowski, K., Pei, K., Scherer-Lorenzen, M., Shi, X., Scholten, T., Schuldt, A., Trogisch, S., von Oheimb, G., Welk, E., Wirth, C., Wu, Y.-T., Yang, X., Zeng, X., Zhang, S., Zhou, H., Ma, K., and Schmid, B.: Community assembly during secondary forest succession in a Chinese subtropical forest, Ecol. Monogr., 81, 25-41, doi:10.1890/09-2172.1, 2011.

Bruelheide, H., Nadrowski, K., Assmann, T., Bauhus, J., Both, S., Buscot, F., Chen, X.-Y., Ding, B.-Y., Durka, W., Erfmeier, A., Gutknecht, J. L. M., Guo, D., Guo, L.-D., Härdtle, W., He, J.-S., Klein, A.-M., Kühn, P., Liang, Y., Liu, X., Michalski, S., Niklaus, P. A., Pei, K., Scherer-Lorenzen, M., Scholten, T., Schuldt, A., Seidler, G., Trogisch, S., von Oheimb, G., Welk, E., Wirth, C., Wubet, T., Yang, X., Yu, M., Zhang, S., Zhou, H., Fischer, M., Ma, K., Schmid, B., and Muller-Landau, H. C.: Designing forest biodiversity experiments: general considerations illustrated by a new large experiment in subtropical China, Methods Ecol. Evol., 5, 74-89, doi:10.1111/2041-210X.12126, 2014.

Cantón, Y., Solé-Benet, A., de Vente, J., Boix-Fayos, C., CalvoCases, A., Asensio, C., and Puigdefábregas, J.: A review of runoff generation and soil erosion across scales in semiarid south-eastern Spain, J. Arid Environ., 75, 1254-1261, doi:10.1016/j.jaridenv.2011.03.004, 2011.

Cerdà, A.: Seasonal and spatial variations in infiltration rates in badland surfaces under Mediterranean climatic conditions, Water Resour. Res., 35, 319-328, doi:10.1029/98WR01659, 1999.

Chisholm, R. A., Muller-Landau, H. C., Abdul Rahman, K., Bebber, D. P., Bin, Y., Bohlman, S. A., Bourg, N. A., Brinks, J., Bunyavejchewin, S., Butt, N., Cao, H., Cao, M., Cárdenas, D., Chang, L.-W., Chiang, J.-M., Chuyong, G., Condit, R., Dattaraja, H. S., Davies, S., Duque, A., Fletcher, C., Gunatilleke, N., Gunatilleke, S., Hao, Z., Harrison, R. D., Howe, R., Hsieh, C.-F., Hubbell, S. P., Itoh, A., Kenfack, D., Kiratiprayoon, S., Larson, A. J., Lian, J., Lin, D., Liu, H., Lutz, J. A., Ma, K., Malhi, Y., McMahon, S., McShea, W., Meegaskumbura, M., Mohd. Razman, S., Morecroft, M. D., Nytch, C. J., Oliveira, A., Parker, G. G., Pulla, S., Punchi-Manage, R., Romero-Saltos, H., Sang, W., Schurman, J., Su, S.-H., Sukumar, R., Sun, I.-F., Suresh, H. S., Tan, S., Thomas, D., Thomas, S., Thompson, J., Valencia, R., Wolf, A., Yap, S., Ye, W., Yuan, Z., Zimmerman, J. K., and Coomes, D. A.: Scale-dependent relationships between tree species richness and ecosystem function in forests, J. Ecol., 101, 1214-1224, doi:10.1111/1365-2745.12132, 2013.

Cong, W.-F., van Ruijven, J., Mommer, L., De Deyn, Gerlinde B., Berendse, F., Hoffland, E., and Lavorel, S.: Plant species richness promotes soil carbon and nitrogen stocks in grasslands without legumes, J. Ecol., 102, 1163-1170, doi:10.1111/13652745.12280, 2014.
Durán Zuazo, V. H. and Rodríguez Pleguezuelo, C. R.: Soil-erosion and runoff prevention by plant covers. A review, Agron. Sustain. Dev., 28, 65-86, doi:10.1051/agro:2007062, 2008.

Frasson, R. P. D. M. and Krajewski, W. F.: Characterization of the drop-size distribution and velocity-diameter relation of the throughfall under the maize canopy, Agr. Forest Meteorol., 151, 1244-1251, doi:10.1016/j.agrformet.2011.05.001, 2011.

García-Orenes, F., Roldán, A., Mataix-Solera, J., Cerdà, A., Campoy, M., Arcenegui, V., and Caravaca, F.: Soil structural stability and erosion rates influenced by agricultural management practices in a semi-arid Mediterranean agro-ecosystem, Soil Use Manage, 28, 571-579, doi:10.1111/j.1475-2743.2012.00451.x, 2012.

Geißler, C., Kühn, P., Shi, X., and Scholten, T.: Estimation of throughfall erosivity in a highly diverse forest ecosystem using sand-filled splash cups, J. Earth Sci., 21, 897-900, doi:10.1007/s12583-010-0132-y, 2010.

Geißler, C., Kühn, P., Böhnke, M., Bruelheide, H., Shi, X., and Scholten, T.: Splash erosion potential under tree canopies in subtropical SE China, CATENA, 91, 85-93, doi:10.1016/j.catena.2010.10.009, 2012a.

Geißler, C., Lang, A. C., von Oheimb, G., Härdtle, W., Baruffol, M., and Scholten, T.: Impact of tree saplings on the kinetic energy of rainfall - The importance of stand density, species identity and tree architecture in subtropical forests in China, Agr. Forest Meteorol., 156, 31-40, doi:10.1016/j.agrformet.2011.12.005, 2012b.

Geißler, C., Nadrowski, K., Kühn, P., Baruffol, M., Bruelheide, H., Schmid, B., and Scholten, T.: Kinetic energy of Throughfall in subtropical forests of SE China - effects of tree canopy structure, functional traits, and biodiversity, PloS one, 8, e49618, doi:10.1371/journal.pone.0049618, 2013.

Goebes, P., Bruelheide, H., Härdtle, W., Kröber, W., Kühn, P., Li, Y., Seitz, S., von Oheimb, G., and Scholten, T.: Species-Specific Effects on Throughfall Kinetic Energy in Subtropical Forest Plantations Are Related to Leaf Traits and Tree Architecture, PloS one, 10, e0128084, doi:10.1371/journal.pone.0128084, 2015a.

Goebes, P., Seitz, S., Kühn, P., Li, Y., Niklaus, P. A., Oheimb, G. V., and Scholten, T.: Throughfall kinetic energy in young subtropical forests: Investigation on tree species richness effects and spatial variability, Agr. Forest Meteorol., 213, 148-159, doi:10.1016/j.agrformet.2015.06.019, 2015b.

Govers, G. and Poesen, J.: Assessment of the interrill and rill contributions to total soil loss from an upland field plot, Geomorphology, 1, 343-354, doi:10.1016/0169-555X(88)90006-2, 1988.

Guerrero-Campo, J., Palacio, S., and Montserrat-Martí, G.: Plant traits enabling survival in Mediterranean badlands in northeastern Spain suffering from soil erosion, J. Veg. Sci., 19, 457-464, doi:10.3170/2008-8-18382, 2008.

Gunn, R. and Kinzer, G. D.: The terminal velocity of fall for water droplets in stagnant air, J. Meteorol., 6, 243-248, doi:10.1175/1520-0469(1949)006<0243:TTVOFF>2.0.CO;2, 1949.

Guo, Q., Hao, Y., and Liu, B.: Rates of soil erosion in China: A study based on runoff plot data, CATENA, 124, 68-76, doi:10.1016/j.catena.2014.08.013, 2015.

Gyssels, G., Poesen, J., Bochet, E., and Li, Y.: Impact of plant roots on the resistance of soils to erosion by water: a review, Prog. 
Phys. Geogr., 29, 189-217, doi:10.1191/0309133305pp443ra, 2005.

Hall, R. L. and Calder, I. R.: Drop size modification by forest canopies: Measurements using a disdrometer, J. Geophys. Res., 98, 18465, doi:10.1029/93JD01498, 1993.

Herwitz, S. R.: Raindrop impact and water flow on the vegetative surfaces of trees and the effects on stemflow and throughfall generation, Earth Surf. Proc. Land., 12, 425-432, doi:10.1002/esp.3290120408, 1987.

Hooper, D. U., Chapin, F. S., Ewel, J. J., Hector, A., Inchausti, P., Lavorel, S., Lawton, J. H., Lodge, D. M., Loreau, M., Naeem, S., Schmid, B., Setälä, H., Symstad, A. J., Vandermeer, J., and Wardle, D. A.: Effects of Biodiversity on Ecosystem Functioning: A Consensus of Current Knowledge, Ecol. Monogr., 75, 3-35, doi:10.1890/04-0922, 2005.

Hupp, C. R., Osterkamp, W. R., and Howard, A. D. (Eds.): Biogeomorphology, terrestrial and freshwater systems: Proceedings of the 26th Binghamton Symposium in Geomorphology, held 68 October, 1995, Elsevier, Amsterdam, New York, 1 online resource, viii, 347, 1995.

IUSS: World reference base for soil resources 2006: A framework for international classification, correlation and communication, 2006th Edn., World soil resources reports, 103, Food and Agriculture Organization of the United Nations, Rome, ix, 128, 2006.

Jacob, M., Viedenz, K., Polle, A., and Thomas, F. M.: Leaf litter decomposition in temperate deciduous forest stands with a decreasing fraction of beech (Fagus sylvatica), Oecologia, 164, 1083-1094, doi:10.1007/s00442-010-1699-9, 2010.

Jiao, J., Zhang, Z., Bai, W., Jia, Y., and Wang, N.: Assessing the Ecological Success of Restoration by Afforestation on the Chinese Loess Plateau, Restor. Ecol., 20, 240-249, doi:10.1111/j.1526-100X.2010.00756.x, 2012.

Kelty, M. J.: The role of species mixtures in plantation forestry, Forest Ecol. Manage., 233, 195-204, doi:10.1016/j.foreco.2006.05.011, 2006.

Kim, J. K., Onda, Y., Kim, M. S., and Yang, D. Y.: Plotscale study of surface runoff on well-covered forest floors under different canopy species, Quaternary Int., 344, 75-85, doi:10.1016/j.quaint.2014.07.036, 2014.

Körner, C. and Spehn, E. M.: Mountain biodiversity: A global assessment, Parthenon Pub. Group, Boca Raton, xiv, 336, 2002.

Kuznetsova, A., Brockhoff, P. B., and Christensen, R. H.: lmerTest: Tests in Linear Mixed Effects Models, available at: http://cran. r-project.org/web/packages/lmerTest/index.html (last access: 22 June 2015), 2014.

Lang, A. C., Härdtle, W., Bruelheide, H., Geißler, C., Nadrowski, K., Schuldt, A., Yu, M., and von Oheimb, G.: Tree morphology responds to neighbourhood competition and slope in species-rich forests of subtropical China, Forest Ecol. Manage., 260, 17081715, doi:10.1016/j.foreco.2010.08.015, 2010.

Lang, A. C., Härdtle, W., Baruffol, M., Böhnke, M., Bruelheide, H., Schmid, B., von Wehrden, H., von Oheimb, G., and Acosta, A.: Mechanisms promoting tree species co-existence: Experimental evidence with saplings of subtropical forest ecosystems of China, J. Veg. Sci., 23, 837-846, doi:10.1111/j.16541103.2012.01403.x, 2012.

Lavorel, S. and Garnier, E.: Predicting changes in community composition and ecosystem functioning from plant traits: revisiting the Holy Grail, Funct. Ecol., 16, 545-556, doi:10.1046/j.13652435.2002.00664.x, 2002.

Li, Y., Härdtle, W., Bruelheide, H., Nadrowski, K., Scholten, T., von Wehrden, H., and von Oheimb, G.: Site and neighborhood effects on growth of tree saplings in subtropical plantations (China), Forest Ecol. Manage., 327, 118-127, doi:10.1016/j.foreco.2014.04.039, 2014.

Loreau, M.: Biodiversity and Ecosystem Functioning: Current Knowledge and Future Challenges, Science, 294, 804-808, doi:10.1126/science.1064088, 2001.

Martin, C., Pohl, M., Alewell, C., Körner, C., and Rixen, C.: Interrill erosion at disturbed alpine sites: Effects of plant functional diversity and vegetation cover, Basic Appl. Ecol., 11, 619-626, doi:10.1016/j.baae.2010.04.006, 2010.

Morgan, R. P. C.: Soil erosion and conservation, 3rd Edn., Blackwell Pub., Malden, MA, x, 304, 2005.

Mutchler, C. K., Murphree, C. E., and McGregor, K. C.: Laboratory and field plots for erosion research, in: Soil erosion research methods, 2nd Edn., edited by: Lal, R., St. Lucie Press; Soil and Water Conservation Society, Delray Beach, Fla., Ankeny, IA, 1138, 1994.

Nanko, K., Hotta, N., and Suzuki, M.: Evaluating the influence of canopy species and meteorological factors on throughfall drop size distribution, J. Hydrol., 329, 422-431, doi:10.1016/j.jhydrol.2006.02.036, 2006.

Nanko, K., Mizugaki, S., and Onda, Y.: Estimation of soil splash detachment rates on the forest floor of an unmanaged Japanese cypress plantation based on field measurements of throughfall drop sizes and velocities, CATENA, 72, 348-361, doi:10.1016/j.catena.2007.07.002, 2008.

Nanko, K., Watanabe, A., Hotta, N., and Suzuki, M.: Physical interpretation of the difference in drop size distributions of leaf drips among tree species, Agr. Forest Meteorol., 169, 74-84, doi:10.1016/j.agrformet.2012.09.018, 2013.

Nanko, K., Giambelluca, T. W., Sutherland, R. A., Mudd, R. G., Nullet, M. A., and Ziegler, A. D.: Erosion Potential under Miconia calvescens Stands on the Island of Hawaii, Land Degrad. Develop., 26, 218-226, doi:10.1002/ldr.2200, 2015.

Onda, Y., Gomi, T., Mizugaki, S., Nonoda, T., and Sidle, R. C.: An overview of the field and modelling studies on the effects of forest devastation on flooding and environmental issues, Hydrol. Process., 24, 527-534, doi:10.1002/hyp.7548, 2010.

Parsons, A. J., Wainwright, J., Schlesinger, W. H., and Abrahams, A. D.: The role of overland flow in sediment and nitrogen budgets of mesquite dunefields, southern New Mexico, J. Arid Environ., 53, 61-71, doi:10.1006/jare.2002.1021, 2003.

Pérez-Harguindeguy, N., Díaz, S., Garnier, E., Lavorel, S., Poorter, H., Jaureguiberry, P., Bret-Harte, M. S., Cornwell, W. K., Craine, J. M., Gurvich, D. E., Urcelay, C., Veneklaas, E. J., Reich, P. B., Poorter, L., Wright, I. J., Ray, P., Enrico, L., Pausas, J. G., de Vos, A. C., Buchmann, N., Funes, G., Quétier, F., Hodgson, J. G., Thompson, K., Morgan, H. D., ter Steege, H., Sack, L., Blonder, B., Poschlod, P., Vaieretti, M. V., Conti, G., Staver, A. C., Aquino, S., and Cornelissen, J. H. C.: New handbook for standardised measurement of plant functional traits worldwide, Aust. J. Bot., 61, 167-234, doi:10.1071/BT12225, 2013.

Pimentel, D.: World soil erosion and conservation, 1st Edn., Cambridge studies in applied ecology and resource management, Cambridge University Press, Cambridge, XII, 349 pp., 1993. 
Pimentel, D. and Kounang, N.: Ecology of Soil Erosion in Ecosystems, Ecosystems, 1, 416-426, doi:10.1007/s100219900035, 1998.

Pimentel, D., Harvey, C., Resosudarmo, P., Sinclair, K., Kurz, D., McNair, M., Crist, S., Shpritz, L., Fitton, L., Saffouri, R., and Blair, R.: Environmental and Economic Costs of Soil Erosion and Conservation Benefits, Science, 267, 1117-1123, doi:10.1126/science.267.5201.1117, 1995.

Pohl, M., Alig, D., Körner, C., and Rixen, C.: Higher plant diversity enhances soil stability in disturbed alpine ecosystems, Plant Soil, 324, 91-102, doi:10.1007/s11104-009-9906-3, 2009.

Pohl, M., Graf, F., Buttler, A., and Rixen, C.: The relationship between plant species richness and soil aggregate stability can depend on disturbance, Plant Soil, 355, 87-102, doi:10.1007/s11104-011-1083-5, 2012.

Pribyl, D. W.: A critical review of the conventional SOC to SOM conversion factor, Geoderma, 156, 75-83, doi:10.1016/j.geoderma.2010.02.003, 2010.

Puettmann, K. J., Coates, K. D., and Messier, C. C.: A critique of silviculture: Managing for complexity, Island Press, Washington, DC, 1 online resource, xvi, 189, 2009.

Puigdefábregas, J.: The role of vegetation patterns in structuring runoff and sediment fluxes in drylands, Earth Surf. Proc. Land., 30, 133-147, doi:10.1002/esp.1181, 2005.

Quijas, S., Jackson, L. E., Maass, M., Schmid, B., Raffaelli, D., and Balvanera, P.: Plant diversity and generation of ecosystem services at the landscape scale: expert knowledge assessment, J. Appl. Ecol., 49, 929-940, doi:10.1111/j.13652664.2012.02153.x, 2012.

Razafindrabe, B. H., He, B., Inoue, S., Ezaki, T., and Shaw, R.: The role of forest stand density in controlling soil erosion: implications to sediment-related disasters in Japan, Environ. Monit. Assess., 160, 337-354, doi:10.1007/s10661-008-0699-2, 2010.

R Core Team: R: A Language and Environment for Statistical Computing, R Foundation for Statistical Computing, Vienna, Austria, 2013.

Richter, G. (Ed.): Bodenerosion: Analyse und Bilanz eines Umweltproblems, Wissenschaftliche Buchgesellschaft, Darmstadt, 264 pp., 1998.

Romero-Diaz, A., Belmonte-Serrato, F., and Ruiz-Sinoga, J. D.: The geomorphic impact of afforestations on soil erosion in Southeast Spain, Land Degrad. Dev., 21, 188-195, doi:10.1002/ldr.946, 2010.

Scherer-Lorenzen, M.: Biodiversity and Ecosystem Functioning: Basic Principles, in: Biodiversity: Structure and Function: Encyclopedia of Life Support Systems (EOLSS), Developed under the Auspices of the UNESCO, edited by: Barthlott, W., Linsenmair, K. E., and Porembski, S., Eolss Publishers, Oxford, 2005.

Scherer-Lorenzen, M.: The functional role of biodiversity in the context of global change, in: Forests and global change, edited by: Coomes, D. A., Burslem, D. F. R. P., and Simonson, W. D., Ecological reviews, Cambridge University Press, Cambridge, UK, New York, 195-238, 2014.

Seitz, S., Goebes, P., Zumstein, P., Assmann, T., Kühn, P., Niklaus, P. A., Schuldt, A., and Scholten, T.: The influence of leaf litter diversity and soil fauna on initial soil erosion in subtropical forests, Earth Surf. Proc. Land., 40, 1439-1447, doi:10.1002/esp.3726, 2015.
Stokes, A., Atger, C., Bengough, A. G., Fourcaud, T., and Sidle, R. C.: Desirable plant root traits for protecting natural and engineered slopes against landslides, Plant Soil, 324, 1-30, doi:10.1007/s11104-009-0159-y, 2009.

Swanson, M. E., Franklin, J. F., Beschta, R. L., Crisafulli, C. M., DellaSala, D. A., Hutto, R. L., Lindenmayer, D. B., and Swanson, F. J.: The forgotten stage of forest succession: earlysuccessional ecosystems on forest sites, Front. Ecol. Environ., 9, 117-125, doi:10.1890/090157, 2011.

Thornes, J. B.: Vegetation and erosion: Processes and environments, British Geomorphological Research Group symposia series, J. Wiley, Chichester, West Sussex, England, New York, NY, USA, xvii, 518, 1990.

Tsujimura, M., Onda, Y., and Harada, D.: The Role of Horton Overland Flow in Rainfall-runoff Process in an Unchanneled Catchment Covered by Unmanaged Hinoki Plantation, Journal of Japan Society of Hydrology \& Water Resources, 19, 17-24, doi:10.3178/jjshwr.19.17, 2006.

Violle, C., Navas, M.-L., Vile, D., Kazakou, E., Fortunel, C., Hummel, I., and Garnier, E.: Let the concept of trait be functional!, Oikos, 116, 882-892, doi:10.1111/j.2007.0030-1299.15559.x, 2007.

Wainwright, J., Parsons, A. J., and Abrahams, A. D.: Plotscale studies of vegetation, overland flow and erosion interactions: case studies from Arizona and New Mexico, Hydrol. Process., 14, 2921-2943, doi:10.1002/10991085(200011/12)14:16/17<2921::AID-HYP127>3.0.CO;2-7, 2000.

Wischmeier, W. H. and Smith, D. D.: Predicting rainfall erosion losses: a guide to conservation planning, Agriculture handbook, 537, Washington, D.C., 1978.

Xu, X.-L., Ma, K.-M., Fu, B.-J., Song, C.-J., and Liu, W.: Influence of three plant species with different morphologies on water runoff and soil loss in a dry-warm river valley, SW China, Forest Ecol. Manage., 256, 656-663, doi:10.1016/j.foreco.2008.05.015, 2008.

Zhao, G., Mu, X., Wen, Z., Wang, F., and Gao, P.: Soil Erosion, Conservation, and eco-environment Changes in the Loess Plateau of China, Land Degrad. Develop., 24, 499-510, doi:10.1002/ldr.2246, 2013.

Zheng, J.-J., He, X.-B., Walling, D., Zhang, X.-B., Flanagan, D., and Qi, Y.-Q.: Assessing Soil Erosion Rates on Manually-Tilled Hillslopes in the Sichuan Hilly Basin Using 137Cs and 210Pbex Measurements, Pedosphere, 17, 273-283, doi:10.1016/S10020160(07)60034-4, 2007.

Zhou, G., Wei, X., and Yan, J.: Impacts of eucalyptus (Eucalyptus exserta) plantation on sediment yield in Guangdong Province, Southern China - a kinetic energy approach, CATENA, 49, 231 251, doi:10.1016/S0341-8162(02)00030-9, 2002. 